\title{
Enhancing Safety in the Polish High-Methane Coal Mines: an Overview
}

\author{
Nikodem Szlązak ${ }^{1}$ - Dariusz Obracaj ${ }^{1}$ (D) - Justyna Swolkień ${ }^{1}$
}

Received: 22 August 2019 / Accepted: 31 January 2020 / Published online: 6 February 2020

(C) The Author(s) 2020

\begin{abstract}
Polish coal mines are characterized by severe geological conditions and the co-occurrence of natural hazards. These hazards are associated with methane and dust emissions during mining processes which can provide methane, dust or methane-dust explosions. Besides, there are such natural hazards as gas and rock outbursts, rock bursts, spontaneous combustion of coal and environmental heat load. The mutual influences of various geological conditions, as well as the natural hazards, intensify the increase of the methane explosion hazard. The occurrence of methane explosions in the Polish mining industry between 2013 and 2108 are analyzed. Fatal accidents are compared with similar events in the global mining industry. The methods of preventing the explosion hazard as well as methane emission control in the Polish coal mining sector are presented. Methane hazard prevention should be adapted to levels and other natural hazards, especially those related to ventilation of underground mine. The methods of preventing methane emissions into mine excavations are often contrary to the means of preventing other ventilation-related hazards in the underground mine, e.g. the prevention of spontaneous combustion of coal in the goaf of longwall panel. Therefore, the design of longwall panels should be preceded by a detailed analysis of the results of both methane emission prediction and forecast of other ventilation-related hazards.
\end{abstract}

Keywords Multi-seam mining $\cdot$ Methane content $\cdot$ Methane control $\cdot$ Methane drainage $\cdot$ Natural hazards in a mine

\section{Introduction}

The main sources of methane are coal seams because it is autochthonous gas and it is closely related to the coalification process of coal beds in late Carboniferous times. Methane content in the coal seams depends on numerous factors; mainly on the presence or lack of impermeable sediments in overburden that allow or not on degasification and migration of methane into surrounding rocks, where it has been trapped in the pore spaces and structures of methane-bearing strata.

Polish coal mines extract coalbed primarily in the Upper Silesian Coal Basin (USCB), which is characterized by a diversity of coalbed methane occurrences and various methane content in coal seams lying in different parts of the basin. The USCB is located in southern Poland and in the Ostrava-

Dariusz Obracaj obracaj@agh.edu.pl

1 AGH University of Science and Technology, Mickiewicz Av. 30, 30-059 Kraków, Poland
Karvina region of the Czech Republic, with an area of $7400 \mathrm{~km}^{2}[9,14]$. It is the largest coal basin in Poland and one of the largest in Europe [14-16].

Gas contents in the multiple seams vary considerably, both vertically and horizontally. Generally, methane quantities in coal seams increase with depth; however, the most gas-rich interval occurs between 500 and $1100 \mathrm{~m}$ below the ground. Methane contents in the coal seams range from 0.01 to $1.00 \mathrm{~m}^{3} / \mathrm{t}$ coal daf in the shallower strata and up to $20 \mathrm{~m}^{3} / \mathrm{t}$ coal daf in coal seams at the depth $1200 \mathrm{~m}$ below the ground surface at the south part of the USCB. Such distribution of methane content in the coal seams was confirmed, among others, by Kotas [17], Kędzior [15] and Szlązak et al. [37]. The average methane content in coal seams of gassy mines in the south of the USCB is around $10 \mathrm{~m}^{3} / \mathrm{t}$ coal daf [34].

Hence, there is a very large range of methane content in coal seams of the USCB. There are coal seams without impermeable overburden containing only trace amounts of methane. But, there are also coal seams with high methane contents underneath the overlying impermeable thick siltstone or claystone layers. 
Conducting mining operations in coal seams with high methane content without using special measures to control methane, like ventilation, methane drainage, gas monitoring systems, would be impossible. The control of methane emission also depends on other co-occurring natural hazards (spontaneous fires, dust, coal and gas outbursts, rock bursts and environmental heat loads). These preventive actions eliminate methane hazard prevention. In the later part of the article, the notion of natural hazard is understood as a strata-related phenomenon that might have a negative effect on miners or the mine environment. Natural mine hazards associated with seam gas emission, heat and dust are, to various degrees, production-dependent. The risk of dangerous events may increase in the future if the mines strive to improve production by concentrating mining works in one mining region $[31,37$, 40].

Methane control techniques are often the cause of increasing the risk of coal spontaneous coal combustion in the minedout area known as the goaf in longwall mining system. These causes include increased migration of air through the goaf due to the increase in the amount of air for diluting methane in the tailgate road or the improper design of drainage boreholes above the caving zone [29, 32, 40, 44].

On the other hand, spontaneous coal combustion in the goaf may lead to methane explosion followed by a coal dust explosion [29, 36]. Cases of self-ignition of coal followed by methane explosion at sudden air inflow into the goaf with a methane-air mixture are known from mining practice both in Poland [37] and in China [4].

Safety in mines excavating coal seams with high methane content depends on the correct estimation of methane hazard, drawn up predictions of methane release, conducted observations, methane control and undertaken prevention measures.

Techniques of methane drainage while mining in a coal mine can bring both financial benefits for mining entrepreneur and ecological for the environment [8].

However, if the only asset of the mine is the production of coal, then, methane drainage together with other methane control methods are used primarily to ensure safety in the mine. Capital expenditures are incurred through these mines for this purpose. The hazard resulting from the possibility of dangerous concentrations of methane in excavations may lead to disasters. Profits of a mining entrepreneur are then incomparable with not only financial losses but also both marketing and moral ones.

The objectives of this article are to present current methods of methane control during multi-seam extraction by longwall mining in Polish mines. The next part will discuss factors that should be taken into account when designing mining operations in such coalbeds, which are characterized by a strong intensity of other natural hazards such as coal and gas outburst, spontaneous fire and environmental heat loads.

\section{State of Methane Hazard in Polish Coal Mines}

Methane in coal seams constitutes a serious hazard to safety in underground coal mines. Geological conditions of methane occurrence in coal seams, as well as the low permeability of Polish coal, cause the low-methane release without the mining operation. The amount of methane released in a coal mine is closely related with the range of conducted mining works, i.e. the number of longwall panels as well as the number of development headings [34].

Methane emission into the working areas of a mine may lead to dangerous events related to methane ignition or explosion $[4,27,31,36,37,42]$. There is a high risk of a methane explosion in the world mining industry. Chinese coal mines produce globally the largest amount of coal, which is why most methane-related accidents occur there. As shown by Yin et al. [47], the number of methane-related fatalities dropped significantly in the period of 2000-2014. Tong et al. [40] revealed that 21 gas explosions occurred in 2017, and 19 explosions in 2018, respectively.

The number of fatalities resulting from methane events in the Polish and global mining sectors in the last 10 years are presented in Table 1. In Poland, there have been 2 accidents connected with explosions of methane during the 10 last years, resulting in 8 miners losing their lives in relation to 843 in the global mining industry.

The list of events related to methane ignition in coal mining sector is presented in Table 2, according to annual reports of the State Mining Authority in Poland. During the past 6 years, there have been 24 accidents connected with methane ignitions and 1 with the explosion of methane, resulting in 6 miners losing their lives, 15 were seriously injured, and 20 were slightly wounded.

The most common cause of methane ignition was sparking resulting from cutting strong rocks by a shearer in longwall faces or by roadheader in driven headings, respectively. The statistical results show that $64 \%$ of methane-related events have come from this source of methane ignition for last 7 years. Ignition of methane was also found from selfignition of coal in goaf of longwall face (9\%) and electrical spark (9\%). There has not been the explosion of methane in Polish coal mines since 2014. Methane ignition has been one of the main reasons for the 13 accidents since 2014. Only one of the miners lost his life in one of these accidents (MurckiStaszic Coal Mine - Operation Staszic) in 2016. These events occurred in both, driven headings and longwall panels using ' $U$ '-type as well as a ' $Y$ '-type ventilation systems.

The Department of Underground Mining at AGH University of Science and Technology has kept records of the methane emission in Polish coal mines for many years [36-38], mainly based on the State Mining Authority annual reports on mining safety. In Poland in 2018, coal extraction 
Table 1 Fatalities resulting from methane events in Polish and global mining sectors since 2010

\begin{tabular}{llll}
\hline Country & Date & Underground mine & Number of fatalities \\
\hline USA & 5 April 2010 & Upper Big Branch & 29 \\
Russia & 8 May 2010 & Raspadskaya & 90 \\
Turkey & 17 May 2010 & Karadon & 28 \\
Columbia & 16 June 2010 & San Fernando & 73 \\
New Zealand & 19 November 2010 & Pike River & 29 \\
Pakistan & 20 March 2011 & Sorange, Quetta & 52 \\
Poland & 5 May 2011 & Krupinski & 3 \\
Ukraine & 29 July 2011 & Suhodolskaya-Vostochnaya & 19 \\
Russia & 11 February 2013 & Workutinskaja & 18 \\
China & 29 March 2013 & Babao, Jilin & 52 \\
China & 30 October 2013 & Hengyang, Hunan & 29 \\
Ukraine & 17 February 2014 & Siewiernaja & 7 \\
Turkey & 13 May 2014 & Soma & 301 \\
Poland & 6 October 2014 & Myslowice-Wesola-O. Myslowice & 5 \\
Ukraine & 4 March 2015 & Zasyadko & 34 \\
Russia & 25 February 2016 & Vorkuta & 36 \\
Ukraine & 2 March 2017 & Stiepowa & 8 \\
Czech Republic & 20 December 2018 & CSM Stonava & 13 \\
Ukraine & 25 April 2019 & Shidkarbon & 17 \\
\hline
\end{tabular}

Entries in italics indicate fatalities in the Polish mining sector amounted to 63.4 million tonnes. During coal production, about 916.1 million $\mathrm{m}^{3}$ of methane was emitted (total methane emission) thus meaning $1743 \mathrm{~m}^{3} \mathrm{CH}_{4} / \mathrm{min}$ (including $1356.5 \mathrm{~m}^{3} \mathrm{CH}_{4} / \mathrm{min}$ was emitted together with the mine ventilation air).

Table 3 presents the development of methane emission in Polish coal mines in years 2007-2018 and the amount of methane captured by the drainage system and utilized. The relative methane emission oscillated in the range of 10.1 to $14.5 \mathrm{~m}^{3} \mathrm{CH}_{4} / \mathrm{t}$. The increase of methane emissions, despite the decline of coal output, has been observed in recent years. That tendency is caused by the higher methane content of the coal seams as well as increased mining of methane prone coal seams.

Table 4 presents the methane emission from coal mines in 2018. The mines with the highest total methane emission in 2018 are as follows: Budryk Coal Mine $-295.34 \mathrm{~m}^{3} \mathrm{CH}_{4} / \mathrm{min}$, Pniowek Coal Mine-212.01 $\mathrm{m}^{3} \mathrm{CH}_{4} / \mathrm{min}$ and Brzeszcze Coal Mine- $187.69 \mathrm{~m}^{3} \mathrm{CH}_{4} / \mathrm{min}$. The average methane drainage efficiency in 2018 was approximately $34.6 \%$, and the average methane utilization was equal to $64 \%$. What follows is that the past 2 years have seen an increase in effective methane utilization by almost $7 \%$.

In the coming years, it is expected that the methane emission will remain at a similar level in Polish coal mining sector. It will make the methane hazard still dominant in coal mines in Poland. Safe mining will be ensured only if the predictive methane action will be properly selected. The selection of methane preventive measures is closely related to layout and ventilation of longwall panels.

The ventilation system should be dependent on predicted gas emission and chosen at the design stage. Predictive methane action includes identification and control methods of methane emission as well as the means against the accumulation of explosive concentrations in workings. In the predictive methane action in coal mines, the following methods play a dominant role:

- Adequate ventilation to prevent the formation of the layering methane or local methane accumulation in mine workings,

- Methane drainage techniques which consist of drilling cross-measure boreholes from the roadways or from the surface to the de-stressed zone at the roof or the floor of the mined coal seam,

- Monitoring of methane content in accordance with the regulations for locating sensors in particular types of excavations,

- The method of installing additional ventilation devices and installations in places with reduced ventilation intensity and the formation of local methane accumulations.

The air quantities and airflow distribution in the longwall panel are of great importance for maintaining safe concentrations of methane in mine excavations [4, 22, 37]. 
Table 2 List of events related to methane ignition in Polish coal mines in the years 2013-2018

\begin{tabular}{|c|c|c|}
\hline Coal mine & Year & Cause \\
\hline Murcki-Staszic - O. Staszic & 2013 & $\begin{array}{l}\text { Methane ignition from sparks resulting from cutting a strong roof } \\
\text { layer by a shearer }\end{array}$ \\
\hline Murcki-Staszic - O. Staszic & 2013 & $\begin{array}{l}\text { Methane ignition from the friction of the conveyor elements to } \\
\text { sandstone blocks under the shearer }\end{array}$ \\
\hline Rydultowy-Anna & 2013 & $\begin{array}{l}\text { Methane ignition from friction sparks resulting from cutting a strong } \\
\text { roof layer by a shearer }\end{array}$ \\
\hline $\begin{array}{l}\text { Knurow-Szczyglowice- }-\mathrm{O} \text {. } \\
\text { Szczyglowice }\end{array}$ & 2013 & $\begin{array}{l}\text { Methane ignition from sparks resulting from cutting a strong roof } \\
\text { layer by a shearer }\end{array}$ \\
\hline $\begin{array}{l}\text { Sosnica-Makoszowy- } \mathrm{O} \text {. } \\
\text { Sosnica }\end{array}$ & 2013 & The appearance of an open fire from electrical sparks \\
\hline $\begin{array}{l}\text { Sosnica-Makoszowy-O. } \\
\text { Sosnica }\end{array}$ & 2013 & $\begin{array}{l}\text { Local heating of cracked coal in the fence and sparking caused by } \\
\text { the caving of strong roof rocks }\end{array}$ \\
\hline $\begin{array}{l}\text { Borynia-Zofiowka-Jastrzebie- } \\
\text { O. Zofiowka }\end{array}$ & 2013 & $\begin{array}{l}\text { Methane ignition from sparks resulting from cutting a strong roof } \\
\text { layer by a shearer }\end{array}$ \\
\hline Chwalowice & 2014 & $\begin{array}{l}\text { Methane ignition while conducting blasting works in the area of the } \\
\text { intersection with the longwall face to force the caving of roof } \\
\text { rocks }\end{array}$ \\
\hline Budryk & 2014 & $\begin{array}{l}\text { Methane ignition from sparks created as a result of the cutting a } \\
\text { strong roof layer by a roadheader }\end{array}$ \\
\hline Bielszowice & 2014 & $\begin{array}{l}\text { Methane ignition from sparks created as a result of the cutting strong } \\
\text { roof layer by a roadheader }\end{array}$ \\
\hline $\begin{array}{l}\text { Myslowice-Wesola- } \mathrm{O} \text {. } \\
\text { Wesola }\end{array}$ & 2014 & $\begin{array}{l}\text { The commission appointed by the President of the State Mining } \\
\text { Authority found that the cause of methane ignition and explosion } \\
\text { was self-ignition of coal in goaf of longwall face ( } 5 \text { fatalities). }\end{array}$ \\
\hline Sosnica & 2015 & $\begin{array}{l}\text { Methane ignition and fire occurred in the area of the intersection of a } \\
\text { tailgate roadway n } 108 \text { with the face n } 108 \text { in the } 408 / 4 \text { seam, at the } \\
\text { level of } 950 \mathrm{~m} \text {. }\end{array}$ \\
\hline $\begin{array}{l}\text { Myslowice-Wesola-O. } \\
\text { Wesola }\end{array}$ & 2015 & $\begin{array}{l}\text { A dangerous event of methane ignition took place in the } 01 \mathrm{Aw} \\
\text { longwall face in the start-up phase due to cutting of the strong } \\
\text { layer by a shearer, in seam } 510 \text {, at the level of } 665 \mathrm{~m} \text {. }\end{array}$ \\
\hline Rydultowy-Anna & 2015 & $\begin{array}{l}\text { The fire occurred in the roadway7a-E1, behind the line of the } \\
\text { VIII-E1 longwall face in seam 703/1, level } 1067 \mathrm{~m} \text {. }\end{array}$ \\
\hline Ruda-O. Halemba & 2016 & $\begin{array}{l}\text { Sparks created during the cut strong rock by a shearer in the fault } \\
\text { zone }\end{array}$ \\
\hline Krupinski & 2016 & $\begin{array}{l}\text { Sparks created during the cut strong rock by a shearer in the fault } \\
\text { zone }\end{array}$ \\
\hline Murcki-Staszic - O. Staszic & 2016 & $\begin{array}{l}\text { Igniting methane by sparks created during the cut strong rock prone } \\
\text { to sparking by a roadheader }\end{array}$ \\
\hline ZG Brzeszcze & 2016 & $\begin{array}{l}\text { Igniting methane by sparks created during the cut strong rock prone } \\
\text { to sparking by a roadheader }\end{array}$ \\
\hline Murcki-Staszic - O. Staszic & 2016 & $\begin{array}{l}\text { The appearance of an open fire on the upcast shaft bottom due to the } \\
\text { ignition of the considerable volume of methane flowing from the } \\
\text { suddenly unseal area }\end{array}$ \\
\hline Budryk & 2017 & $\begin{array}{l}\text { Methane ignition from sparks created during the cut strong rock } \\
\text { prone to sparking by a roadheader }\end{array}$ \\
\hline ZG Brzeszcze & 2017 & $\begin{array}{l}\text { Methane ignition from sparks created during the cut strong rock by a } \\
\text { shearer in the fault zone }\end{array}$ \\
\hline $\begin{array}{l}\text { Borynia-Zofiówka-Jastrzębie- } \\
\text { O. Zofiowka }\end{array}$ & 2017 & $\begin{array}{l}\text { Methane ignition from sparks created during the cut strong rock } \\
\text { prone to sparking by a roadheader during drivage of heading in } \\
\text { coal seam } 505 / 1 \text { at level of } 900 \mathrm{~m}\end{array}$ \\
\hline $\begin{array}{l}\text { Borynia-Zofiówka-Jastrzębie- } \\
\text { O. Zofiowka }\end{array}$ & 2018 & $\begin{array}{l}\text { Methane ignition from sparks created during the cut sandstone in the } \\
\text { roof layer by a shearer in the fault zone }\end{array}$ \\
\hline Murcki-Staszic - O. Staszic & 2018 & $\begin{array}{l}\text { Methane ignition from sparks created during the cut interfered } \\
\text { sandstone in coal seam by a shearer }\end{array}$ \\
\hline
\end{tabular}


Table 3 The balance of methane emissions in Polish coal mining sector for the last 12 years

\begin{tabular}{|c|c|c|c|c|c|c|c|c|c|c|c|c|}
\hline Year & 2007 & 2008 & 2009 & 2010 & 2011 & 2012 & 2013 & 2014 & 2015 & 2016 & 2017 & 2018 \\
\hline Total methane emission (million $\mathrm{m}^{3} /$ year) & 878.9 & 880.9 & 855.7 & 834.9 & 828.8 & 828.2 & 847.8 & 891.1 & 933.0 & 933.8 & 948.5 & 916.1 \\
\hline Ventilation air methane (million $\mathrm{m}^{3} /$ year) & 610.1 & 606.7 & 595.9 & 579.0 & 578.6 & 561.5 & 581.7 & 570.1 & 594.0 & 591.7 & 611.5 & 599.1 \\
\hline $\begin{array}{l}\text { Methane obtained from the drainage system (million } \\
\mathrm{m}^{3} / \text { year) }\end{array}$ & 268.8 & 274.2 & 259.8 & 255.9 & 250.2 & 266.7 & 276.6 & 321.0 & 339.0 & 342.1 & 337.0 & 317.0 \\
\hline Amount of utilized methane (million $\mathrm{m}^{3} /$ year) & 165.7 & 156.5 & 159.5 & 161.1 & 166.3 & 178.6 & 187.7 & 211.4 & 197.1 & 195.0 & 212.0 & 203.1 \\
\hline $\begin{array}{l}\text { Methane emission to the atmosphere (million } \mathrm{m}^{3} / \text { year) } \\
\text { (line. } 2+\text { line } .3 \text { - line } 4 \text { ) }\end{array}$ & 713.2 & 724.4 & 690.7 & 673.8 & 662.5 & 649.6 & 660.1 & 679.7 & 735.9 & 738.8 & 736.5 & 713.0 \\
\hline Coal output (million tonnes) & 87.4 & 83.6 & 77.3 & 76.1 & 75.5 & 79.2 & 76.5 & 72.5 & 72.2 & 70.4 & 65.5 & 63.4 \\
\hline
\end{tabular}

\section{Longwall Ventilation Systems}

Over the years, Polish mining industry has developed practical rules for longwall panel development for balancing costs incurred on the number of gate roads with income earned from rate of face advances. These rules, of course, take into account the coexistence of ventilation-related natural hazards. It has led to the application of currently only of retreat longwall faces.

In Polish coal mines, there is still a mistaken belief that the ventilation of longwall panels depends on the development of
Table 4 Methane emission in Polish coal mines in year 2018 (based on data from [43])

\begin{tabular}{|c|c|c|c|c|c|c|c|c|}
\hline \multicolumn{2}{|c|}{ Coal mine } & \multirow[t]{3}{*}{ Operation } & \multicolumn{6}{|c|}{ Methane content } \\
\hline & & & \multicolumn{2}{|c|}{$\begin{array}{l}\text { Methane obtained } \\
\text { from drainage system }\end{array}$} & \multicolumn{2}{|c|}{$\begin{array}{l}\text { Ventilation air } \\
\text { methane, VAM }\end{array}$} & \multicolumn{2}{|c|}{$\begin{array}{l}\text { Total methane } \\
\text { emission }\end{array}$} \\
\hline & & & $\begin{array}{l}\mathrm{m}^{3} \mathrm{CH}_{4} / \\
\min \end{array}$ & $\begin{array}{l}\mathrm{mln} \\
\mathrm{m}^{3} \mathrm{CH}_{4} / \\
\text { year }\end{array}$ & $\begin{array}{l}\mathrm{m}^{3} \mathrm{CH}_{4} / \\
\min \end{array}$ & $\begin{array}{l}\mathrm{mln} \\
\mathrm{m}^{3} \mathrm{CH}_{4} / \\
\text { year }\end{array}$ & $\begin{array}{l}\mathrm{m}^{3} \mathrm{CH}_{4} / \\
\min \end{array}$ & $\begin{array}{l}\mathrm{mln} \\
\mathrm{m}^{3} \mathrm{CH}_{4} / \\
\text { year }\end{array}$ \\
\hline \multirow[t]{3}{*}{1} & Ruda & O. Bielszowice & 5.23 & 2.75 & 41.11 & 21.61 & 46.35 & 24.36 \\
\hline & & O. Halemba & 6.68 & 3.51 & 28.39 & 14.92 & 35.06 & 18.43 \\
\hline & & O. Pokoj & N.O. & N.O. & 2.26 & 1.19 & 2.26 & 1.19 \\
\hline \multirow[t]{4}{*}{2} & ROW & O. Jankowice & 18.26 & 9.6 & 37.18 & 19.54 & 55.44 & 29.14 \\
\hline & & O. Chwalowice & 20.21 & 10.62 & 28.01 & 14.72 & 48.21 & 25.34 \\
\hline & & O. Marcel & 9.11 & 4.79 & 29.81 & 15.67 & 38.93 & 20.46 \\
\hline & & O. Rydultowy & 14.63 & 7.69 & 33.35 & 17.53 & 47.98 & 25.22 \\
\hline 3 & Budryk & & 119.82 & 62.98 & 175.51 & 92.25 & 295.34 & 155.23 \\
\hline 4 & Knurow & zczyglowice & 17.69 & 9.3 & 95.68 & 50.29 & 113.38 & 59.59 \\
\hline 5 & Sosnica & & 30.73 & 16.15 & 49.35 & 25.94 & 80.08 & 42.09 \\
\hline 6 & Makosz & & N.O. & N.O. & 0.89 & 0.47 & 0.89 & 0.47 \\
\hline 7 & Śląsk & & 2.68 & 1.41 & 1.81 & 0.95 & 4.49 & 2.36 \\
\hline 8 & Brzeszc & & 94.03 & 49.42 & 93.66 & 49.23 & 187.69 & 98.65 \\
\hline 9 & Silesia & & 31.53 & 16.57 & 27.07 & 14.23 & 58.6 & 30.8 \\
\hline 10 & Murcki- & aszic & 22.09 & 11.61 & 60.79 & 31.95 & 82.88 & 43.56 \\
\hline 11 & Myslow & -Wesola & 39.4 & 20.71 & 94.84 & 49.85 & 134.25 & 70.56 \\
\hline 12 & Wujek & & 11.89 & 6.25 & 13.79 & 7.25 & 25.68 & 13.5 \\
\hline 13 & Wieczol & & N.O. & N.O. & 28.33 & 14.89 & 28.33 & 14.89 \\
\hline 14 & Wieczol & & N.O. & N.O. & 13.28 & 6.98 & 13.28 & 6.98 \\
\hline 15 & Jas-Mos & & 16.61 & 8.73 & 0.36 & 0.19 & 16.97 & 8.92 \\
\hline 16 & Brzeszc & Wschod & N.O. & N.O. & 22.51 & 11.83 & 22.51 & 11.83 \\
\hline 17 & Borynia & ofiowka-Jastrzebie & 31.49 & 16.55 & 123.19 & 64.75 & 154.68 & 81.3 \\
\hline 18 & Pniowel & & 81.47 & 42.82 & 130.54 & 68.61 & 212.01 & 111.43 \\
\hline 19 & Krupins & & 29.51 & 15.51 & 8.07 & 4.24 & 37.58 & 19.75 \\
\hline \multicolumn{3}{|c|}{ Total } & 603.06 & 316.97 & 1139.78 & 599.08 & 1742.87 & 916.05 \\
\hline
\end{tabular}

The notation N.O. used in the table means not occur 
the operation in the coalbed and the progress of the development works as well as the operating variables related to the coal output, direction of haulage, the transport of materials, the power supply etc. In fact, the choice of ventilation system should be determined by the condition of the predicted natural hazards, which are ventilation-related. Such hazards like methane emission or emanation from strata, coal and gas outbursts, spontaneous fires or environmental heat load should take place at the stage of the design development works. The ventilation of the mining district should be customized to levels of predicting natural hazards. The decisive factor of determining the ventilation should be the coexistence of methane emission with the risk of spontaneous fires and thermal work conditions in the longwall panels.

The minimum mean velocity of the airflow both in roadways and in longwall faces is $0.3 \mathrm{~m} / \mathrm{s}$ in coal fields with methane contents. The maximum mean velocities are $5 \mathrm{~m} / \mathrm{s}$ in faces and $8 \mathrm{~m} / \mathrm{s}$ in roadways, respectively. Practically, the velocity in the faces ranges from 2.5 to $3.5 \mathrm{~m} / \mathrm{s}$. However, the ventilation system must allow the possibility of providing $5 \mathrm{~m} / \mathrm{s}$. According to Polish mining regulations, if the maximum allowable concentration of methane in the workings reaches $2 \%$ vol., electricity is turned off, and extra measurements are taken. Then, active methods of reducing concentration are selected. If the concentration of methane reaches $3 \%$ vol., miners are withdrawn from the dangerous area, and further actions are carried out on the special principles of a rescue operation.

The required air velocities determine the airflow rates. In gas fields, the airflows in the longwall panel usually range between 800 and $3500 \mathrm{~m}^{3} / \mathrm{min}$ depending on both the coal seam thickness and methane emission. Ventilation networks of coal mines are extensive and very complex. Mines lead to less face advance rate during the release of methane. Therefore, there may be even a dozen or so longwall panels in such mines, but most often number does not exceed a few panels. Total airflow rate in the mines reaches up to a few thousands of cubic metres per minute. Mining is usually multi-levels with a few shafts, and main fan collar pressures are usually in the range from 2000 to $3500 \mathrm{~Pa}$. The minimum static pressure required by law and regulations at the outlet of upcast shaft is $785 \mathrm{~Pa}$.

The most frequently used ventilation systems for retreat longwall panels at the moment are [37]:

- A 'U'-type ventilation system,

- A 'U'-type ventilation system with parallel return roadway,

- A 'Y'-type ventilation system:

- Return side ventilation system,

- With return air distribution in two directions (bleeder system).
Fig. 1 The most popular localisation of the additional ventilation devices for methane control in the tailgate for the ' $U$ '-type ventilation of the longwall panel. a The layout of ' $U$ '-type ventilation system. b The using of the 'wing curtains' and air-movers. $\mathbf{c}$ The using of the brattice and air-movers. $\mathbf{d}$ The using of the ducting and air-movers

In Polish gassy mines, a number of preventive measures are used to conduct safe longwall mining. Among them, one can mention the increase of airflow rates, methane drainage and the monitoring of methane release into workings. Sometimes it is necessary to use additional devices or ventilation installations to the control of gas emissions (see Fig. 1). With the installation of an additional ventilation facility in the tailgate, the values of methane concentration can maintain below $2 \%$ vol. Methane sensors with functions, both real-time concentration recording and de-energizing electrical devices, are applied to a continuous atmospheric monitoring system.

In most cases, additional ventilation devices are used to lower the methane concentrations in the zone of crossing the face outlet with the tailgate road. There are both curtains called 'wing curtain' and air-movers powered with the compressed air, which are designed to direct the air to the side of the liquidation of the tailgate road behind the line of longwall face. Increased airflow rates in this zone dilute methane. In the case of increased methane emission, the so-called mixing chamber is used. The idea of a 'mixing chamber' consists in dividing the section of the tailgate with two parts using a brattice. In this way, ventilation similar to the ' $\mathrm{Y}$ '-type system is obtained. Beside, recirculation of air into the 'mixing chamber' can be carried out. Supply fresh air provided by ducting to the 'mixing chamber' is the other solution. Such ventilation solutions are described, inter alia, in the works [33, 37].

Intensive ventilation of longwall panels is conducted in order to dilute methane emitted to workings so that its concentration drops to the level required by the mining regulations aimed at guaranteeing work safety. However, such ventilation is often either insufficient to ensure planned mining-process parameters or impossible to be employed without additional devices or ventilation installations. Therefore, methane drainage is implemented in coal mines during mining activities [33]. Geological properties (porosity, permeability, reservoir pressure, diffusivity) of coal seams, coalbed methane content and low desorption of Polish coal seams result in low gas emission without disturbing the structure of strata. Therefore, the amount of released methane is closely connected with the range and scale of mining activities, both during the development stage and during mining process [18].

The 'U'-type ventilation system for retreating longwall panels limits the control of methane emission due to the lack of possibilities of effective methane drainage. Szlazak et al. [34] showed that the efficiency of methane drainage with such ventilation system is on average $40 \%$. Although, this 
a)

Tailgate road

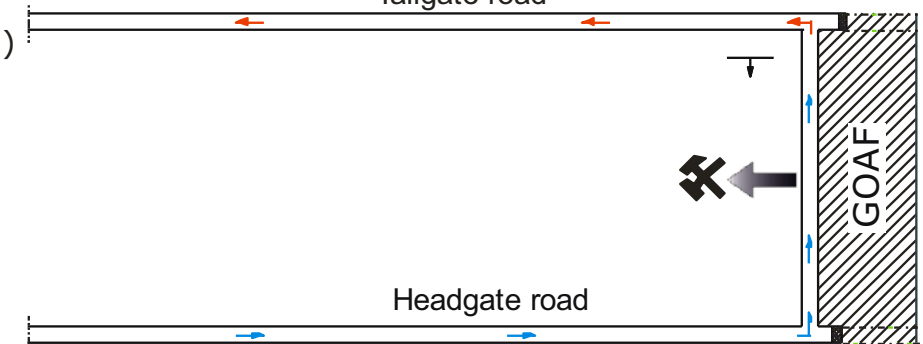

b)

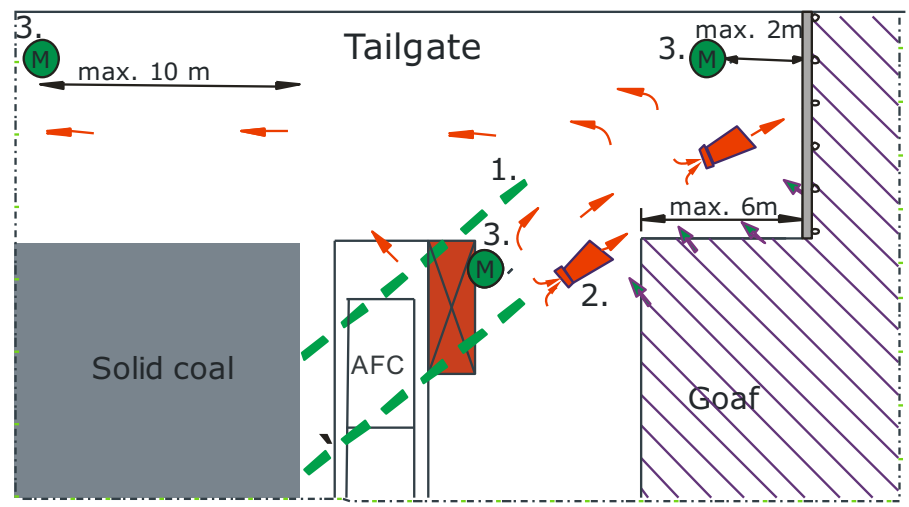

C)

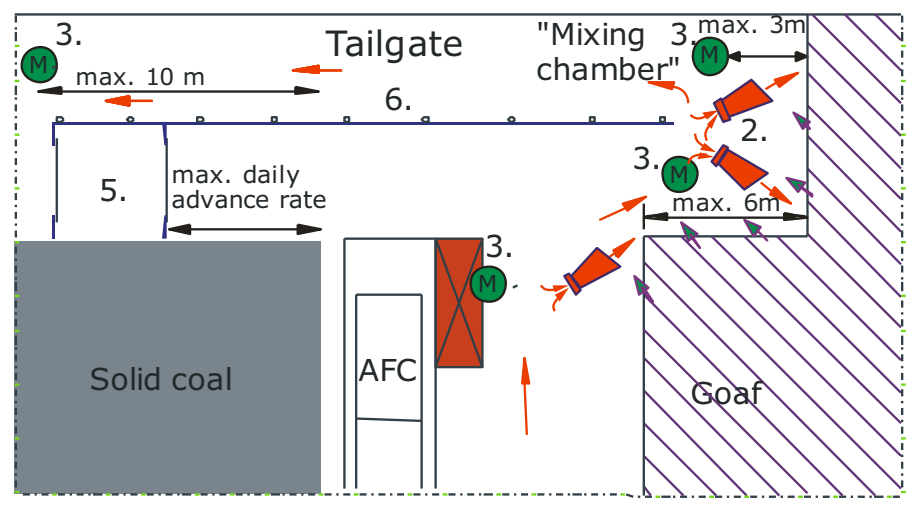

d)

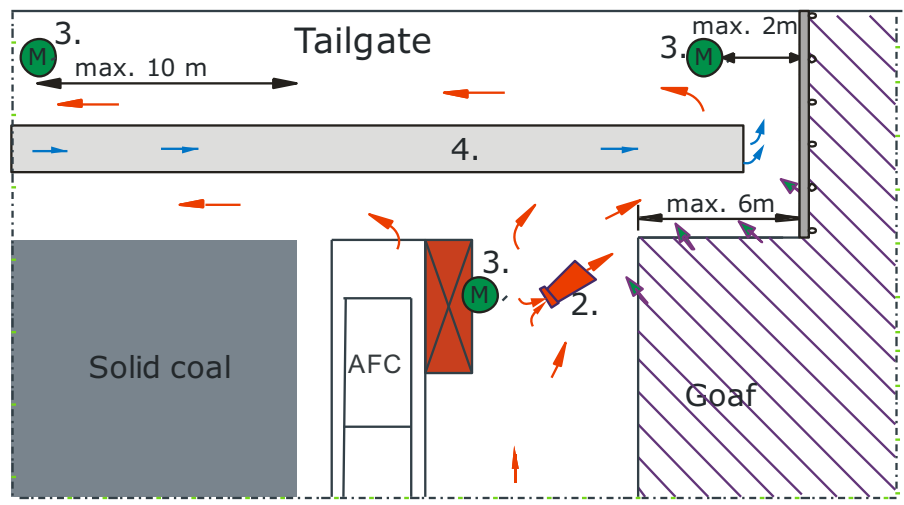

LEGEND:

1. Wing curtain

2. Air-mover powered with the compressed air

3. Methane sensor

4. Ducting with the fresh air

5. Airlock with doors

6. Brattice 
efficiency depends on the total methane emission and may increase up to $50 \%$ at emissions greater than $50 \mathrm{~m}^{3} / \mathrm{min}$. The relatively low efficiency of methane capture results from the small emission from the worked-seam and the need to degas the over- and underlying coal seams. It may cause difficulties in maintaining safe concentrations of methane, especially in low-height faces because of the difficulties in supplying the required airflow in the face.

The ' $U$ '-type ventilation system effectively limits the progress of coal spontaneous coal combustion. It ensures limited airflow through goaf and lowers the spontaneous fire only in the case of proper longwall face advance rate. The complicated tectonics of coal seams and geological disturbances might cause problems in obtaining the extraction advance that minimizes spontaneous fire risk. In the case of spontaneous fire in goaf of longwall panel, this system reduces the possibilities of its elimination. In the case when there is serious methane hazard with limited face advance rate and spontaneous coal combustion occurs. This system makes it difficult to combat with co-occurring hazards effectively.

It is necessary to apply additional solutions and ventilation devices that do not completely bring the expected results. An example is the use of an additional force ducting in the tailgate road which supplies fresh air to the tailgate of the face. The fresh air flowing out of the duct should dilute the methane in the zone of the tailgate. This solution should be used when operating low-height panels when there is no possibility of increasing the airflow in the face. However, it was widely used for all panels and assumed in technical projects. The correct approach is to calculate the required airflow in the face and to carry out such regulation in the ventilation network so that this airflow is ensured. The use of ducting with fresh air should be treated as an additional, not as the main protection against methane emission in the zone of the face outlet.

It happens that methane emission to the airways during extraction of longwall panels is significantly higher than estimated in the technical project. Therefore, the replacing classic ' $U$ '-type system with parallel return roadway is necessary but generates additional costs (second return roadway).

The ' $U$ '-type ventilation system in Polish coal mining is generally used in longwall panels classified under the categories of I and II of methane hazard (Polish classification of methane hazard in coal mines, which criterion is the methane content in the coal), while categories of III and IV require its use in combination with effective methane drainage [36]. Classification of whole mines or particular coal seams to methane hazard is based on methane content in coal, expressed in cubic metres of methane per tonne of coal daf. This classification can be found, inter alia, in the work of Kędzior [14] or Szlazzak et al. [37].

The ' $\mathrm{Y}$ '-type ventilation system (various types) is used to control methane in longwall panels with high methane emission. The system is appropriate for either gassy or non-gassy longwall panels, or panels with or without high risk of spontaneous combustion of coal. Also, these longwall panels achieve the record level of advance rates and coal output.

The ' $\mathrm{Y}$ '-type return side ventilation system is used for panels in low-thickness seams with high methane emission. It allows movement of methane concentration towards goaf from the longwall face. Intake air is supplied by two roadways (headgate road and tailgate road). After the longwall face is ventilated, the gases are mixed with fresh air and removed by goaf-side tailgate road. This system also helps in controlling thermal working conditions when there are high environmental heat loads at the outlet of the longwall face. The 'Y'-type ventilation system with return air distribution in two directions (bleeder system) is convenient for longwall panels of low and medium thickness of coal seams [33].

The 'U'-type ventilation system with parallel return roadway, sometimes known as 'back return system', is used in conditions of very highly predicted methane emission. Intake air is supplied to the longwall face through two roadways: the headgate road and the interior tailgate road, and return air flows through the second (overlying) tailgate road sometimes termed the exterior return roadway. The main advantage of this system is the possibility of extra airflow supply which affects the limit of methane concentrations, the possibility of controlling airflow in the longwall and convenience in draining methane of over- and underlying coal seams. The typical localisation of the additional ventilation devices are presented in Fig. 2.

Additional ventilation devices for controlling methane in the longwall face can be used in various places of the panel depending on the local gas outflow. Such devices are also used at the entrance to the face. An example of the location of such devices, together with methane sensors, is shown in Fig. 3.

If there is no possibility of diluting methane below the permissible concentrations in workings, drainage techniques must be used, thus preventing the gas entering the ventilating airstream. However, the right combination of ventilation systems and drainage methods is required.

\section{Longwall Methane Drainage}

The degasification of strata is categorized as pre-drainage or post-drainage methods in relation to coal extraction. These methods can be divided into surface-to-mine boreholes or in-mine boreholes [48]. The Polish mining industry uses only underground post-drainage methods using in-mine boreholes to the relaxed strata, usually during and rare after coal extraction. These methods are the most effective method of controlling methane emission to longwall faces in a multi-seam mining condition. They ensure gas capturing from overlying and/ or underlying source in relaxed zones created during mining operations. Next, the gas is transporting to the surface through 
Fig. 2 The localisation of the additional ventilation devices for methane control in the tailgate for 'U'-type ventilation system with parallel return roadway. a The layout of the ventilation system. b The using of additional ventilation devices

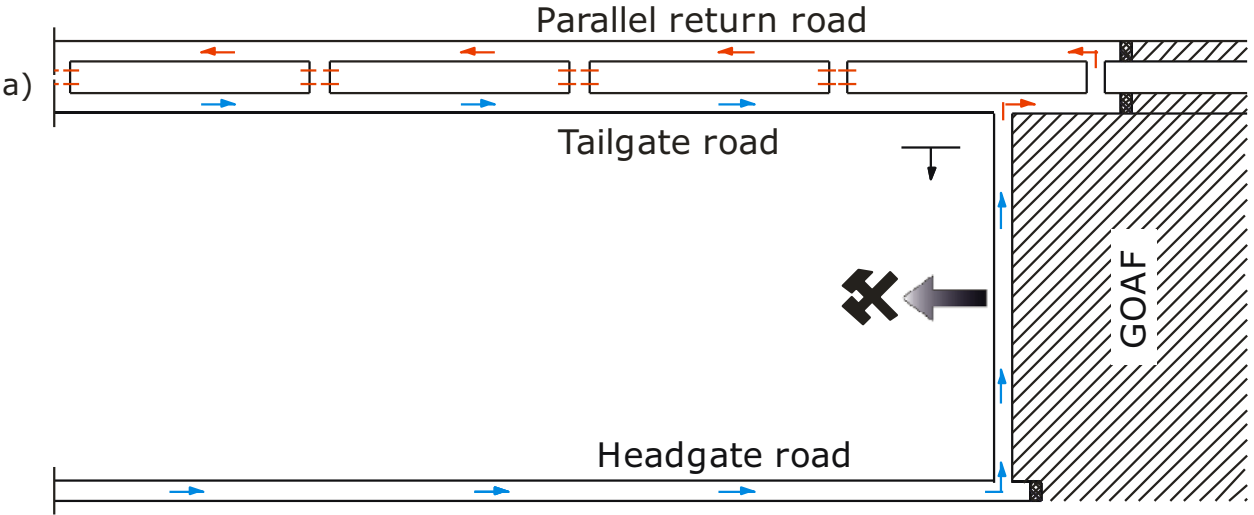

b)

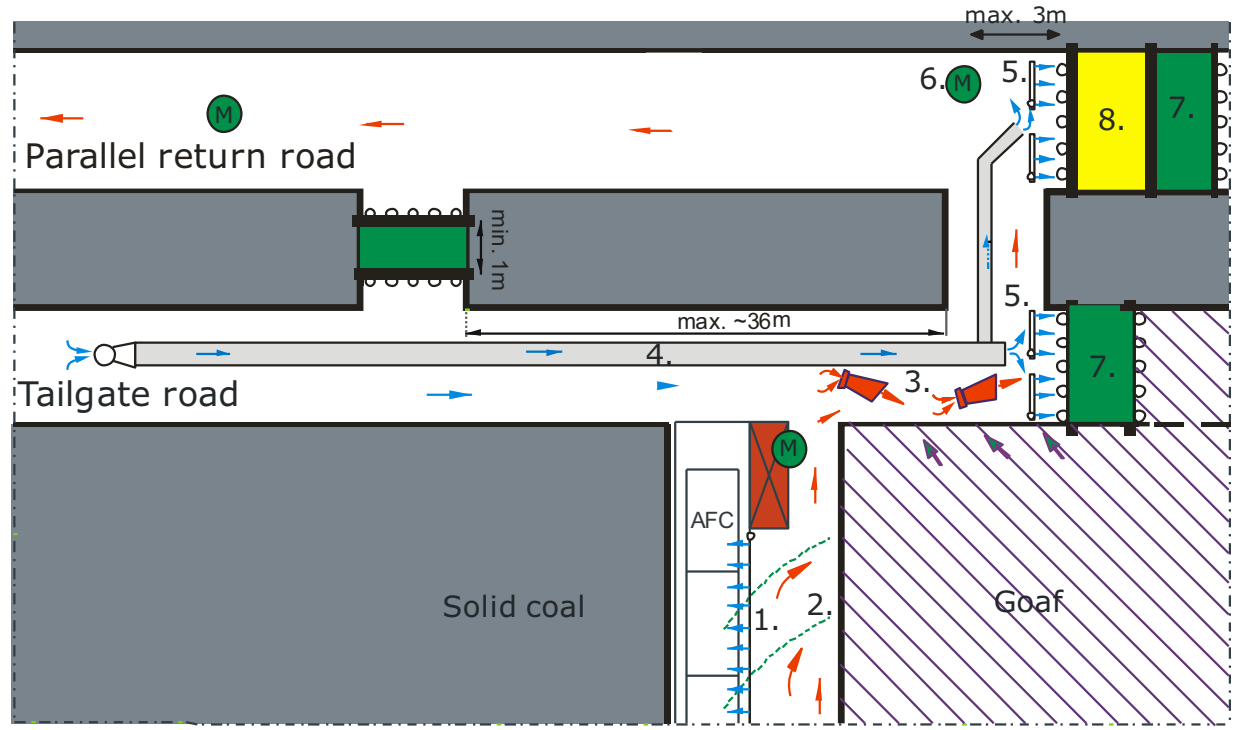

LEGEND:

1. Compressed air nozzles under the AFC

2. Wing curtain

3. Air-mover powered with the compressed air

4. Ducting with the fresh air

5. Compressed air nozzles directed at the seal

6. Methane sensor

7. Seal made of chemical agents

8. Seal made of quick-setting agents pipelines, using the negative pressure from drainage station extractors [1]. The known methods of drill holes in working seam are not used due to the very low permeability of Polish coal seams. Also, apturing from the goaf areas of the active longwall panels using surface wells is not carried out due to the considerable depth of coal extraction.

However, other non-mining entities attempt pre-drainage techniques. Two projects were launched, one in the Wesola Coal Mine and the other in the Gilowice area. The first, pilot project, was related to two surface goaf wells into coal seam 510 , vertical well and the pilot well, respectively. The coal seam had to be hydraulically fractured with these wells in order to achieve methane capturing. The gas pre-drainage effect for the safety coal seam extraction by mining methods has not been confirmed because it was not decided to develop the works in that part of the seam. The second one is a pilot project in the virgin coal deposit within the framework of coalbed methane recovery and utilization. The third project in the Bielszowice mine is at the design stage. The projects are carried out by Polish Oil and Gas (PGNiG) company in cooperation with other partners [10,28].

All these activities are used to test support development of CBM production technologies. So far, no direct effect has been shown to improve safety when coal is extracted. Therefore, the Polish mining sector focuses on post-drainage methods to ensure the safety of the mining process. 
Fig. 3 The localisation of the additional ventilation devices for methane control in the headgate for ' $U$ '-type ventilation system

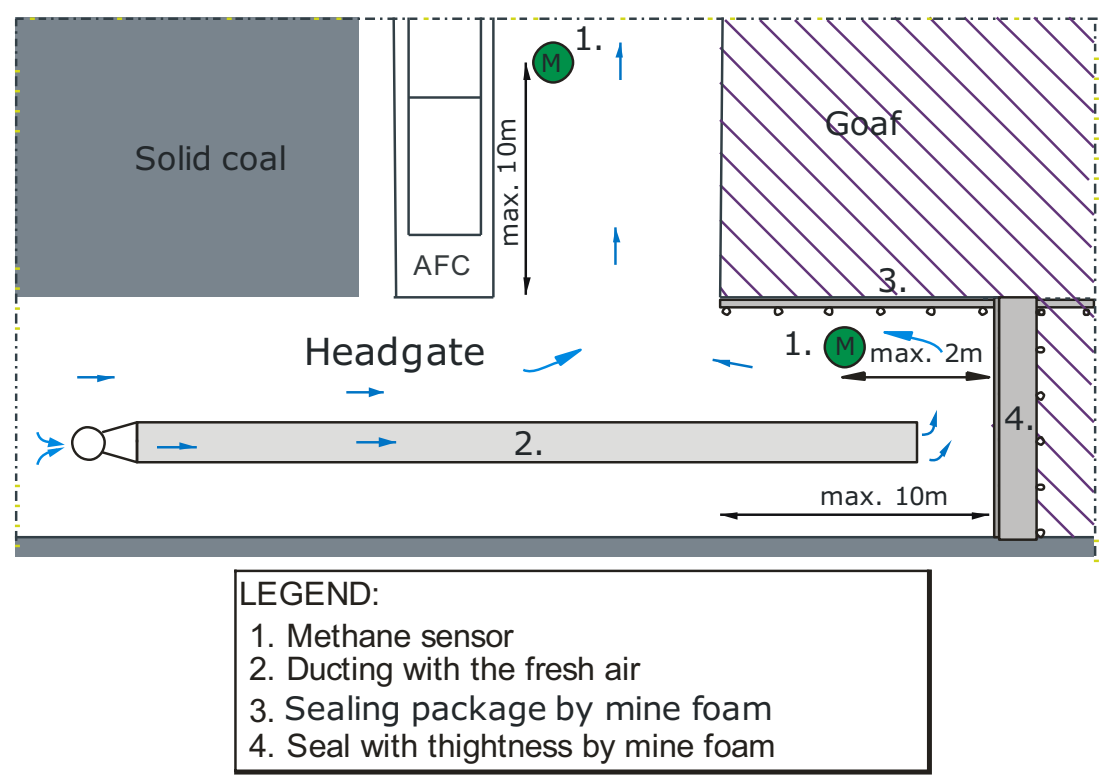

The methane drainage performance from goaf areas in Polish mining is given very often. However, it should be noted that the mines present methane extraction from behind sealed goaf areas by in-mine techniques. Again, non-mining entities extract methane from the goaf areas of abandoned mines using surface vertical wells as abandoned mine methane (AMM) or abandoned goaf/gob methane (AGM) extraction, but the extracted gas is not included in the methane balance of Polish coal companies (Table 3 ).

At this point, it should also be noted that in the Polish mining industry, laboratory IUMK-1 installation for methane recovery from ventilation air with the thermal capacity of $1 \mathrm{~kW}$ at the shaft VI in the Jas-Mos Coal Mine was launched in 2012 [23, 39].

In Polish coal mines, in the case of methane-rich coal seams under high pressure, prior selection of overlying or underlying coal seams for extraction is applicable. This is one of the methods of gas and coal outburst prevention. These mining techniques contribute to the permeabilityincreasing area of the protected coal seam [50]. However, in the USCB, there are numerous, thin, methane-rich coal seams between the seams expected to be extracted. Therefore, this technique is sporadically used in Polish mining, and methane drainage technologies evolve.

There are two technologies of gas drainage applied in the Polish coal mining industry. The first one involves drilling cross-measure boreholes from the roadways to the mininginduced fracture zones in the overlying or underlying strata. The location of the cross-measure boreholes depends on the longwall panel design as well as the ventilation system $[5,6$, $37,45]$.

It is necessary to determine the boundaries of the natural gas emission zone in mining-induced strata for applying methane drainage boreholes within adjacent (overlying and underlying) coal seams $[25,26]$.

Through theoretical research and many investigations, this zone in the overlying strata is divided into three vertical zones named caving, fracture and constrained, respectively. Many researchers conducted the rules for determining these zones $[1,2,6,7,11,12,25,26,36,46,50,51]$. A detailed analysis of the development of research on the determination of these zones was presented by Majdi et al. [21]. Degassing of overburden is effective if the drainage boreholes cross the fracture zone and reach the constrained zone, but they should not cross the caving zone [34]. The most effective boreholes are these, which enter a fracture zone but in the area where there is a significant dominance of tensional stress over compression stress. The tensional stress zone is located on the edge of the longwall panel, in contrast to the occurrence of compressional stress in the centre of the panel development. In the rock mass with tensional stress, there are through-going vertical fractures, and they are gas migration pathways in fractured strata $[6,7,11,12,25,49]$.

The length and inclination of boreholes must be chosen such that they should cross the fracture zone until the constrained zone. Szlazak et al. [35] give the method of determining this zone on the base of the theoretical model given by Flügge G. in 1971. Determining the size of the degassing zone in the geological conditions of the USCB was also presented, among others, by Krause and Lukowicz [18] and Szlązak et al. [34].

The second method involves drilling drainage heading in overworked or underworked coal seams; therefore, it is called the overlying or underlying drainage method [35], detailing the rules for the location of the excavation in the fracture zone. 
The location of drilled boreholes is dependent on development methods of panels and ventilation systems. There are various forms of panel layout for retreat longwall mining. These forms depend on the number of gate roads, which develop the panel. The ventilation is related to the form of panel layout. The results of drainage efficiency in longwall panels with different variations of ventilation systems were presented in publications as follows: $[13,33,37,38,41]$. The average methane drainage efficiency in the last 10 years was $54 \%$. The lowest methane drainage efficiency of $41 \%$ was obtained in panels with a 'U'-type ventilation system. The highest average methane drainage efficiency, which was equal to $63 \%$, was obtained in longwalls with a 'U'-type ventilation system with a parallel tailgate roadway and an overlying drainage heading. In longwall panels with a 'Y-type' system, methane drainage efficiency amounted to $49 \%$ [38].

In recent years, in-mine directional drilling technology into the fractured zone has advanced, and the concept of long boreholes equipped with perforated pipes has been proposed. It is planned that piped-boreholes should work on the boundary of the caving and fracture zones over the longwall face [24].

Although these drainage methods ensure the desired parameters of ventilation, they impose certain requirements concerning the development of works in gassy coal seams.

The concluded analysis by Szlązak et al. [34] has shown that the highest efficiency of methane drainage has been achieved by means of both the 'U'-type ventilation system with the parallel return roadway and the classic $U$ system with the overlying drainage heading, respectively.

The lowest methane drainage efficiency was obtained in panels with a classic 'U'-type system. This ventilation system is not effective at very high methane emissions due to the difficulty of capturing gas from above goaf of active longwall, which is important for the multi-seam extraction. Regarding the efficiency of methane drainage that has been obtained in Polish mines, the predicted methane emission into excavations of longwall panel with a ' $U$ '-type ventilation system should not exceed $20 \mathrm{~m}^{3} \mathrm{CH}_{4} / \mathrm{min}$. The methane drainage system or change in the ventilation system must be used in this case.

When a typical ' $Y$ '-type system of ventilation is implemented, the air-tightness of boreholes drilled from the tailgate road behind the longwall face diminishes over time. It is caused by the progressing degradation of the tailgate road and the fact that casing pipes are placed in the immediate proximity of the goaf. The length and inclination of boreholes must be chosen such that over- or underlying seams are intersected. Poor positioning of the holes can lead to an increase in a spontaneous combustion of coal in the goaf, especially if its prone to the self-heating process is high $[3,19]$. When the location of boreholes or drainage pressure inside them is too large, some of the air leaking from the working face can increase the risk of spontaneous fire in the goaf area $[19$, 29].

By contrast, the ventilation system with parallel return roadway leaves a coal pillar between them (Fig. 2), which makes it possible to achieve enduring air-tightness of casing pipes, resulting in a mixture of gases with higher methane concentration. However, the coal pillars and a pack cavity system means that more coal remains in the goaf area. If the leakages of air through this area are significant, they may also increase the self-heating process of coal [20, 30, 37, 44].

Very often, there are several natural hazards in Polish mines that can lead to disasters. Besides co-occurrence of the methane explosion and spontaneous fire hazards, there is a hazard of coal dust explosion, a hazard of the rock-gas outburst and a hazard of a rockburst. Also, there is a very high risk of working in a hot microclimate in Polish mines, which can lead to clinical disorders as a result of thermal stress [36]. Planning of specific coal extraction in the conditions of so many hazards should be a multiple-stage process and executed in the right order concerning the security of all mining operations.

Szlazak et al. [36, 38] proposed a design procedure adapted to the co-occurring hazards, which assumes planning a method of coal seam extraction adapted to the predicted hazards instead of a so far method of selecting those prophylaxes to the adopted method of the extraction.

\section{Conclusions}

The presented methane balance analysis of Polish coal mines shows an increase in methane emission over several years due to the higher share of the number of gassy coal seams in the exploitation of coal deposits. However, it is expected that the level of methane emission will be maintained at a similar level in the following years. Therefore, methane emission will still be the dominant hazard in Polish coal mining.

In order to improve safety during mining operations surrounded by many natural hazards, the design of mining works must be preceded by detailed analyses of the expected level of risk to these hazards. The proposed algorithm for designing mining works in the vicinity of many natural hazards with a predominant methane hazard may help improve safety. The main design principle should be the selection of the method of the mining operation to the expected level of natural hazards. The matching the prevention measures to the previously designed coal extraction method is not proper procedure.

The design and planning of longwall panels in methane-rich coal seams should entail the further detailed prediction of the methane emission rate. On the prediction results, a ventilation system, a methane drainage method and other additional measures to prevent the accumulation of dangerous methane concentrations in mine excavations should be selected. The solutions should not adversely affect the risk of spontaneous fires and do not worsen the micro-climatic conditions at workplaces.

In the geological conditions of Polish mines, the 'U'-type ventilation system is most often used. In the case of increased methane release at the outlet of the face, the additional ventilation 
devices such as 'mixing chamber', ducting with fresh air or airmovers powered with the compressed air are used with positive effect. In the conditions of Polish mines, the 'U'-type ventilation system is most often used. In the case of increased methane release at the outlet of the face of the wall, the ventilation equipment such as ducting with fresh air, wing curtains, air-movers or set of nozzles powered with the compressed air are used with positive effect. The methane drainage with definite efficiency or another ventilation system must be applied in the case of prediction of methane emissions above $20 \mathrm{~m}^{3} \mathrm{CH}_{4} / \mathrm{min}$.

In the case of expected high methane emissions, it is a good solution to vent longwall panels by the ' $\mathrm{Y}$ '-type return side ventilation system together with cross-measure boreholes in conjunction with suitably adapted fire prevention measures or to use the ' $U$ '-type ventilation system with an overlying drainage heading. In both cases, it is also necessary to use real-time monitoring systems to control the concentrations of both methane and other gassy products of self-heating process of the coal. Such solutions, together with the observance of general safety rules, cause the safety of exploitation of methane-rich coal seams in Polish mines does not differ from the global mining industry.

Funding Information This research is financially supported by the Ministry of Science and Higher Education for statutory research and development (No. 16.16.100.215 in AGH-UST).

\section{Compliance with Ethical Standards}

Conflict of Interest The authors declare that they have no conflict of interest.

Open Access This article is licensed under a Creative Commons Attribution 4.0 International License, which permits use, sharing, adaptation, distribution and reproduction in any medium or format, as long as you give appropriate credit to the original author(s) and the source, provide a link to the Creative Commons licence, and indicate if changes were made. The images or other third party material in this article are included in the article's Creative Commons licence, unless indicated otherwise in a credit line to the material. If material is not included in the article's Creative Commons licence and your intended use is not permitted by statutory regulation or exceeds the permitted use, you will need to obtain permission directly from the copyright holder. To view a copy of this licence, visit http://creativecommons.org/licenses/by/4.0/.

\section{References}

1. Aitao Z, Kai W (2016) Airflow stabilization in airways induced by gas flows following an outburst. J Nat Gas Sci Eng 35(part A): 720 725. https://doi.org/10.1016/j.jngse.2016.08.078

2. Aitao Z, Kai W (2018) A new gas extraction technique for high-gas multi-seam mining: a case study in Yangquan Coalfield, China. Environ Earth Sci 77(2018):150-116. https://doi.org/10.1007/s12665018-7291-z

3. Balusu R., Belle B. \& Tanguturi K (2019) Development of goaf gas drainage and inertisation strategies in $1.0-\mathrm{km}-$ and $3.0-\mathrm{km}-$ long panels. Min Metal Explor (2019). https://doi.org/10.1007/s42461019-0071-9, 36, 1127, 1136
4. Cheng J (2018) Explosions in underground coal mines: risk assessment and control. Springer International Publishing AG, part of Springer Nature. https://doi.org/10.1007/978-3-319-74893-1

5. Guo H, Todhunter C, Qu Q, Qin Z (2015) Longwall horizontal gas drainage through goaf pressure control. Int $\mathrm{J}$ Coal Geol 150-151: 276-286. https://doi.org/10.1016/j.coal.2015.09.003

6. Guo H, Yuan L, Shen B, Qu Q, Xue J (2012) Mining-induced strata stress changes, fractures and gas flow dynamics in multi-seam longwall mining. Int J Rock Mech Min Sci 54:129-139. https:// doi.org/10.1016/j.ijrmms.2012.05.023

7. Hu S, Zhang A, Feng G, Guan S, Guo X, Li C, Xu G (2017) Impact of coalbed incidence angle on methane enrichment zone in longwall gob. Minerals 7(9):166. https://doi.org/10.3390/min7090166

8. Hummel J, Ruiz FA, Kelafant JR (2018) Quantifying the benefits of coal mine methane recovery and use projects: case study on the application of in-mine horizontal pre-drainage boreholes at gassy coal mines in India and the optimization of drainage system design using reservoir simulation. Environ Technol Innov 10:223-234. https://doi.org/10.1016/j.eti.2018.03.003

9. Jureczka J, Kotas A (1995) Coal deposits-Upper Silesian Coal Basin. In: Zdanowski A, Żakowa H (eds) The carboniferous system in Poland, 0866-9465, vol 148. Geological Institute, Warszawa, pp 164-173

10. Jureczka J, Kasza P, Kroplewski $Ł$ (2018) Pre-mine drainage of methane from coal seams in the USCB-Geo-Methane Program. XXVII School of Underground Mining Session-Coal Mine Methane as a Valuable Energy Source Krakow, February $28^{\text {th }}$ 2018. Available online: https://www.unece.org/fileadmin/DAM/ energy/images/CMM/CMM_CE/SEP__11._Pre-mine_Drainage of_Methane_from_Coal_Seams_in_the_USCB_\%E2\%80\%93 Geo-Methane_Program.pdf

11. Karacan CÖ, Goodman GVR (2009) Hydraulic conductivity changes and influencing factors in longwall overburden determined by slug tests in gob gas ventholes. Int J Rock Mech Min Sci 46: 1162-1174. https://doi.org/10.1016/j.jirmms.2009.02.005

12. Karacan CÖ, Olea RA (2014) Inference of strata separation and gas emission paths in longwall overburden using continuous wavelet transform of well logs and geostatistical simulation. J Appl Geophys 105:147-158. https://doi.org/10.1016/j.jappgeo.2014.03. 019

13. Karacan CÖ, Ruiz FA, Cote M, Phipps S (2011) Coal mine methane: a review of capture and utilization practices with benefits to mining safety and to greenhouse gas reduction. Int J Coal Geol 86: 121-156. https://doi.org/10.1016/j.coal.2011.02.009

14. Kedzior S (2009) Accumulation of coalbed methane in the southwest part of the Upper Silesian Coal Basin (southern Poland). Int J Coal Geol 80:20-34. https://doi.org/10.1016/j.coal.2009.08.003

15. Kedzior S (2015) Methane contents and coal-rank variability in the Upper Silesian Coal Basin, Poland. Int J Coal Geol 139:152-164. https://doi.org/10.1016/j.coal.2014.09.009

16. Kędzior S, Kotarba MJ, Pękała Z (2013) Geology, spatial distribution of methane content and origin of coalbed gases in Upper Carboniferous (Upper Mississippian and Pennsylvanian) strata in the south-eastern part of the Upper Silesian Coal Basin, Poland. Int J Coal Geol 105:24-35. https://doi.org/10.1016/j.coal.2012.11.007

17. Kotas A (1994) Coal-bed methane potential of the Upper Silesian Coal Basin, Poland. Prace Panstwowego Instytutu Geologicznego, CXLII0866-9465. Polish Geological Institute, Warsaw (81 pp.)

18. Krause E, Łukowicz K (2004) Methane drainage in Polish hard coal mines. Achievements and Perspectives. In: The 11th International Scientific and Technical Conference "Rockbursts 2004" - New solutions in the field of preventing rockbursts and methane hazards, 8-10 November 2004, Ustron, Poland (in Polish)

19. Li L, Qin B, Ma D, Zhuo H, Liang H, Gao A (2018) Unique spatial methane distribution caused by spontaneous coal combustion in 
coal mine goafs: an experimental study. Process Saf Environ Prot 116:199-207. https://doi.org/10.1016/j.psep.2018.01.014

20. Lu Y, Qin B (2015) Identification and control of spontaneous combustion of coal pillars: a case study in the Qianyingzi mine, China. Nat Hazards 75(3):2683-2697. https://doi.org/10.1007/s11069014-1455-2

21. Majdi A, Hassani FP, Nasiri MY (2012) Prediction of the height of destressed zone above the mined panel roof in longwall coal mining. Int J Coal Geol 98:62-72. https://doi.org/10.1016/j.coal.2012. 04.005

22. Mishra DP, Panigrahi DC, Kumar P (2018) Computational investigation on effects of geo-mining parameters on layering and dispersion of methane in underground coal mines-a case study of Moonidih Colliery. J Nat Gas Sci Eng 53:110-124. https://doi. org/10.1016/j.jngse.2018.02.030

23. Nawrat S, Napieraj S (2012) Pro-ecological technology of mine methane utilization. AGH J Min Geoeng 36:253-261 http:// journals.bg.agh.edu.pl/MINING/2012.36.3/mining.2012.36.3.253. pdf

24. Obracaj D, SWOLKIEŃ J (2016) Method of methane drainage with using the cased long boreholes. Economic Commission for Europe Committee on Sustainable Energy Group of Experts on Coal Mine Methane Eleventh session Geneva, 24-25 October 2016 https:// www.unece.org/fileadmin/DAM/energy $/ \mathrm{se} / \mathrm{pp} / \mathrm{coal} / \mathrm{cmm} / 11 \mathrm{cmm}$ oct2016/a9_Methane.drainage_Poland_OBRACAJ_SWOLKIEN. pdf

25. Palchik V (2003) Formation of fractured zones in overburden due to longwall mining. Environ Geol 44:28-38. https://doi.org/10.1007/ s00254-002-0732-7

26. Palchik V (2005) Localization of mining-induced horizontal fractures along rock layer interfaces in overburden: field measurements and prediction. Environ Geol 48:68-80. https://doi.org/10.1007/ s00254-005-1261-y

27. Pejic LM, Torrent JG, Querol E, Lebecki K (2013) A new simple methodology for evaluation of explosion risk in underground coal mines. J Loss Prev Process Ind 26:1524-1529. https://doi.org/10. 1016/j.jlp.2013.08.021

28. PGNiG (2019) Available online: http://en.pgnig.pl/news/-/newslist/id/coal-bed-methane-fueled-power-generation-unit-launchedby-pgnig-in-gilowice/newsGroupId/1910852

29. Qin B, Li L, Ma D, Lu Y, Yuwei J (2016) Control technology for the avoidance of the simultaneous occurrence of a methane explosion and spontaneous coal combustion in a coal mine: a case study. Process Safety and Environmental Protection 103 (Part A), 203211. DOI: https://doi.org/10.1016/j.psep.2016.07.005

30. Qin J, Qu QD, Guo H (2017) CFD simulations for longwall gas drainage design optimization. Int J Min Sci Technol 27(5):777-782. https://doi.org/10.1016/j.ijmst.2017.07.012

31. Shi L, Wang J, Zhang G, Cheng X, Zhao X (2017) A risk assessment method to quantitatively investigate the methane explosion in underground coal mine. Process Saf Environ Prot 107:317-333. https://doi.org/10.1016/j.psep.2017.02.023

32. Song ZY, Kuenzer C (2014) Coal fires in China over the last decade: a comprehensive review. Int J Coal Geol 133:72-99. https:// doi.org/10.1016/j.coal.2014.09.004

33. Szlazak N, Borowski M, Obracaj D (2008) Directions of changes in ventilation system of longwalls with attention on reduction ventilating hazards. Mineral Resources Management. vol. 24. issue 1/2. (in Polish)

34. Szlązak N, Borowski M, Obracaj D, Swolkień J, Korzec M (2014a) Comparison of methane drainage methods used in polish coal mine. Arch Min Sci 59(3):655-675. https://doi.org/10.2478/amsc-20140046

35. Szlązak N, Obracaj D, Swolkień J (2014b) Methane drainage from roof strata using an overlying drainage gallery. Int J Coal Geol 136: 99-115. https://doi.org/10.1016/j.coal.2014.10.009
36. Szlązak N, Obracaj, D, Borowski M., Swolkień J., Korzec M (2016) Methane in Polish coal mines-methods of control and utilisation. The 24th World Mining Congress proceedings: mining in a world of innovation. Rio de Janeiro: IBRAM. pp. 287-297

37. Szlązak N, Borowski M, Obracaj D, Swolkień J, Korzec M, Piergies K (2017) Current ventilation problems in hard coal mines. Nikodem Szlązak (ed), AGH University of Science and Technology Press (Wydawnictwa AGH). Krakow, Poland

38. Szlązak N, Obracaj, D, Swolkień J (2019) Methods of methane control in Polish coal mines. Proceedings of the 11th International mine ventilation congress. Ed. By Xintan Chang. Science Press; Springer Nature Singapore Pte Ltd., ISBN: 978-981-13-1419-3. pp. 292-307

39. Sztekler K, Komorowski M, Kot D (2016) Modelling of the energy use of ventilation air from the mines. E3S Web of Conferences, $1^{\text {st }}$ International Conference on the Sustainable Energy and Environment Development (SEED 2016). https://doi.org/10.1051/ e3sconf $/ 20161000094$

40. Tong R, Yang Y, 1, Ma X, Zhang Y, Li S, Yang H (2019) Risk assessment of miners' unsafe behaviors: a case study of gas explosion accidents in coal mine, China Int J Environ Res Public Health 2019, 16, 1765; doi:https://doi.org/10.3390/ijerph16101765

41. United Nations Economic Commission for Europe (UNECE) (2016) Best practice guidance for effective methane drainage and use in coal mines (Second Edition). ECE Energy Series No. 47. United Nations Publication. https://doi.org/10.18356/d114d3dd8-en

42. Wang GF, Ren T, Cook CD (2014) Goaf frictional ignition and its control measures in underground coal mines. In: The $2^{\text {nd }}$ International Symposium of Mine Safety Science and Engineering. Beijing, China, pp 451-459

43. WUG, 2019. Available online: http://www.wug.gov.pl/bhp/stan bhp_w_gornictwie ()

44. Xia TQ, Zhou FB, Gao F, Kang JH, Liu JS, Wang JG (2015) Simulation of coal self-heating processes in underground methane-rich coal seams. Int J Coal Geol 141-142:1-12. https:// doi.org/10.1016/j.coal.2015.02.007

45. Xue J, Wang H, Zhou W, Ren B, Duan C, Deng D (2015) Experimental research on overlying strata movement and fracture evolution in pillarless stress-relief mining. Int J Coal Sci Tech 2(1): 38-45. https://doi.org/10.1007/s40789-015-0067-0

46. Yan H, He F, Yang T, Li L, Zhang S, Zhang J (2016) The mechanism of bedding separation in roof strata overlying a roadway within a thick coal seam: a case study from the Pingshuo Coalfield, China. Eng Fail Anal 62:75-92. https://doi.org/10.1016/j. engfailanal.2015.12.006

47. Yin W, Fu G, Yang C, Jiang Z, Zhu K, Gao Y (2017) Fatal gas explosion accidents on Chinese coal mines and the characteristics of unsafe behaviors: 2000-2014. Saf Sci 92:173-179

48. Zheng C, Jiang B, Xue S, Chen Z, Li H (2019) Coalbed methane emissions and drainage methods in underground mining for mining safety and environmental benefits: a review. Process Saf Environ Prot 127:103-124. https://doi.org/10.1016/j.psep.2019.05.010

49. Zhang C, Tu S, Zhang L, Bai Q, Yuan Y, Wang F (2016) A methodology for determining the evolution law of gob permeability and its distributions in longwall coal mines. J Geophys Eng 13(2). https://doi.org/10.1088/1742-2132/13/2/181

50. Zhang R, Cheng Y, Zhou H, Yuan L, Li W, Liu Q, Jin K, Tu Q (2018) New insights into the permeability-increasing area of overlying coal seams disturbed by the mining of coal. J Nat Gas Sci Eng 49:352-364. https://doi.org/10.1016/j.jngse.2017.11.031

51. Zuber MD (1998) Production characteristics and reservoir analysis of coalbed methane reservoirs. Int J Coal Geol 38:27-45. https:// doi.org/10.1016/S0166-5162(98)00031-7

Publisher's Note Springer Nature remains neutral with regard to jurisdictional claims in published maps and institutional affiliations. 